\title{
COVEY T. OlIVER (1913-2007)
}

\section{By William D. Rogers*}

Eric Sevareid once said that there were three sorts of people: the mowers of lawns, the well poisoners, and the life enhancers. Covey Oliver was of that small third group. He excelled across the spectrum of public policy-as an exciting pundit of the law, a superb law teacher, and a public servant at the highest levels of diplomacy.

He was Texas born and bred. A Texas twang imbued not only his English, but also his excellent Spanish and Portuguese. He graduated from that state's university and its law school in 1936 and quickly began his lifetime career of teaching. But there was no keeping him away from the action. He answered Washington's call and served with the Department of State's Bureau of Economic and Business Affairs and the Board of Economic Warfare through the darkest days of World War II, from late 1941 to 1949 . It was his responsibility to round up vital raw materials for the war effort from wherever in the world they could be found. At one point he was even detailed to officially neutral, but agent-infested Spain, where he was charged with keeping strategic war materials out of the hands of the Axis. And when the conflict ended, he found himself in the thick of the titanic challenges posed by the war's destruction and the postwar efforts of this country and its European Allies to repair the wreckage through the Marshall Plan.

In 1949 Oliver moved to Berkeley and taught there until 1956, when he switched to the University of Pennsylvania Law School. He taught international law at Penn, with time off for government service, until 1978. He served briefly as acting dean and retired in that year.

During his tenure at Penn, President John F. Kennedy appointed him the part-time U.S. member of the Inter-American Juridical Committee of the Organization of American States, where he quickly made his mark on the hemisphere's international legal traditions. Then, taking leave from Penn in 1964, he was sent to Colombia as U.S. ambassador. In 1967 President Lyndon B. Johnson brought him back to the State Department to name him assistant secretary for the entire Latin American Bureau.

Only when the Johnson administration was drawing to a close in 1969 did he return to Penn to resume his classroom duties. He had earlier found time to serve as an associate reporter of the American Law Institute's Restatement (Second) of the Foreign Relations Law of the United States, published in 1965. While at Penn he also co-authored the widely used Cases and Materials on the International Legal System, first published in 1973 and later updated several times.

Covey Oliver's service on this Journal's Board of Editors was both lengthy and invaluable. He was first elected as a regular member in 1954 and served in that capacity, except for a hiatus during his government service, until 1977; he was made an honorary editor for life in 1978. He wrote the Judicial Decisions section from January 1961 through April 1963, reporting on both international courts and groups of national decisions by U.S. and European courts on subjects of international law such as nationality and extradition. Among them figured such notable cases as the Temple of Preah Vihear, Certain Expenses of the United Nations, the Lawless Case, Banco Nacional de Cuba v. Sabbatino, and Attorney-General of Israelv. Eichmann. He also

* Washington, D.C. 
contributed an article, and numerous Editorial Comments and book reviews to the Journal. He served as president of the American Society of International Law from 1982 to 1984.

I first knew Covey Oliver when I was a freshly minted associate at Arnold, Fortas and Porter in Washington. He would occasionally drop by the firm on his official consultation visits from Bogotá to trade sallies with Thurman Arnold, to whom he was distantly related, and Abe Fortas. He was greatly admired by the senior partners, and staggeringly impressive to the juniors of the firm who were seeing a live American ambassador for the first time. Perhaps the general admiration for him, and the Fortas and Arnold links through the Democratic Party to Kennedy and later the Johnson White House were not entirely unrelated to his being called back to public service in the sixties.

In any event, I had full opportunity to measure Oliver's tenure as assistant secretary, when I succeeded to that office in 1974 and could see for myself his impact on the department. It was compelling evidence of what someone of towering intelligence, wit, a well-honed pen, and an endearing capacity for self-mockery can have on the Department of State. Leadership works.

The Latin American regional bureau was not, prior to the Kennedy era, a refuge for the best and the brightest in the department; indeed, it was encumbered by doctrinal ancients, many all too stuffy in the nineteenth-century diplomatic tradition and so conservative by temperament as to be suspicious of Latin leaders who talked of reform, development, and social change. The Latin American Bureau in the early 1960 s was mostly persuaded that the essence of U.S. policy in the region should be to entrench adequate defenses against the spread of the Cuban revolution and to play ball with the oligarchs. The Kennedy administration tried to change that attitude and create a more positive, constructive, and dynamic American policy, through the Alliance for Progress. Johnson persisted. Ambassador Oliver was the perfect instrument for revolutionizing our hemispheric policy at the operational level, office by office in the department itself. I could still trace the differences he had made when I became assistant secretary some six years later.

His public service was a model. But no tribute to him in this Journal would be complete without full acknowledgment of his legal scholarship, his publications, and his teaching career. He could write superbly; he spoke compellingly; and he personified the highest ideals of the profession-scrupulous intellectual honesty, a respect for both the is and the ought of the law, and an ability to distinguish the one from the other.

He was a worthy president of this Society, one who enjoyed and deserved the admiration of his colleagues in full measure.

\section{THE FRANCIS DEÁK PRIZE}

The Board of Editors is pleased to announce that the Francis Deák Prize for 2007 was awarded to Christine Bell of the University of Ulster for her article entitled Peace Agreements: Their Nature and Legal Status, which appeared in the April 2006 issue.

The prize was established by Philip Cohen in memory of Dr. Francis Deák, an international legal scholar and lifelong member of the American Society of International Law, to honor a younger author who has published a meritorious contribution to international legal scholarship in the American Journal of International Law. 